\title{
JURISDIÇÃO EXTRATERRITORIAL EM DIREITO DA CONCORRÊNCIA: BALANÇO E PERSPECTIVAS
}

EXTRATERRITORIAL JUIRISDICTION IN COMPETITION LAW: BALANCE AND PERSPECTIVIS

Ana Paula Martinez

\begin{abstract}
Resumo:
A matéria aborda o exercicio da jurisdição extraterritorial, necessário, uma vez que um mesmo ato pode afetar significativamente mais de uma jurisdição.

Palavras-chave: Exercício da jurisdição extraterritorial. Antitruste. Defesa da concorrência.
\end{abstract}

\begin{abstract}
:
This article refers to the exercise of the extraterritorial jurisdiction. necessary, once in one exactly act more than one jurisdiction can act significantly.
\end{abstract}

Keywords: Exercise of the extraterritorial jurisdiction. Antitrust. Competition defense

1. Introdução

É direito fundamental do Estado o exercício da jurisdição' em seu território. Além disso, pode o Estado, em certas situações, exercer sua jurisdição extraterritorialmente, i.e., sobre pessoas, direitos ou relações jurídicas existentes além de suas fronteiras. ${ }^{2}$

A jurisdição extraterritorial em matéria de defesa da concorrência vem sendo adotada pelos Estados por várias razões. Com efeito, é crescente o número de empresas multinacionais (por vezes ativas apenas por meio de exportações) que podem envolver-se em estruturas ou condutas lesivas à concorrência em vários países. A extensão da jurisdição justifica-se também pelo fato de que as legislações antitruste têm

A Autora é advogada em São Paulo. Mestre em Direito Internacional pela Faculdade de Dircito da Universidade de Sĩo Paulo.

1 O termo "jurisdição" será entendido em sua acepção mais ampla. como o poder do Estado soberano de legislar, aplicar exceutar suas normas jurídicas.

2 Hả que se ressaltar que a jurisdição extraterritorial não deve comportar um juizo de valor a priori sobre a legitimidade da competência extraterritorial reivindicada. Porém, fato é que o termo acabou ganhando uma conotação pejorativa. levando a uma condenação prévia do campo de aplicação ampliado que um Estado confere a sua própria legislação, considerado na maioria das vezes ilegitimo por ferir a soberania de outros Estados. Nesse sentidu, ver RFNOLD, Marc-André. Les conflits de lois en droil antitrust - Contribution à l'étude de V application internationale du droit économique. Zürich: Schulthess Polygraphischer Verlag, 1991. p. 144. e IDOT, Laurence. Le controle des pratiques restrictives de concurrenci dans Is échanges internationaux. Thèse: Paris II, 1981. v. 2. p. 487. 
natureza tipicamente protecionista e a tendência é que cada país preocupe-se, de fato, somente com a preservação da concorrência que afete o seu mercado. Por exemplo, nos Estados Unidos, nos termos do Webb-Pomerane $\mathrm{Act}$, de 1918 " 3 é conferida imunidade antitruste a cmpresas que direcionam suas atividades exclusivamente para o exterior. Assim, uma conduta anticoncorrencial pode ser praticada totalmente no país A com vistas a atingir exclusivamente o mercado de um país $B$. Para proteger seus interesses, o país B objetivará a aplicação de sua lei de defesa da concorrência àquela conduta cometida no país A, com a subseqüente geração de efeitos extraterritoriais. Se assim não fosse. cartéis de exportação formados nos Fstados Unidos que gerassem efeitos no Brasil, por exemplo, poderiam ficar impunes. O tema ganha importância em vista do crescente número de paises que adotam legislação antitruste com alcance extraterritorial. o que traz consigo os riscos de conflitos decorrentes de sua aplicação.

O presente trabalho está dividido em sete partes. Após um confronto entre aplicação e efeitos extraterritoriais da lei, far-se-á uma análise dos elementos de conexão que mais interessam em direito da concorrência. Posteriormente, será feito um balanço do exercício da jurisdição extraterritorial por parte de Estados Unidos, União Européia ${ }^{4}$ e Brasil, o que será seguido por breve análisc das crises provocadas pelo exercício dessa jurisdição ampliada. Em seguida, trataremos das perspectivas do exercício de jurisdição extraterritorial em matéria antitruste. Por fim. serão expostas as conclusões.

\section{Confronto entre aplicação extraterritorial e efeito extraterritorial da lei}

A distinção entre aplicação extraterritorial de uma lei e seus efeitos extraterritoriais é bastante limitada. Como ensina Marc-André Renold, "les deux notions ne sont que Vavers et le revers de la même médaille, Vaction 't son résultat" "Com

15 U.S.C., 61-65. O Export Trading Company ACt (ETCA), de 1982, instituiu o chamado export frade cerrificate of review, que confere a seus titulares empresas que atendem somente o mercado extemo. imunidade antitruste penal e relacionada à indenizaçào por treble damages, nos limites cstabelecidos no certificado e durante seu periudo de validade. Outro pais que adota previsào legal semelhante é o Canadá. Nos termos do Canadian Comperition Act. R.S., 1985. c. C-34. $\$ \$ 45(5)$ e 45(6). uma conduta ilicita pode nào ser condenada se $o$ acordo for voltado exclusivamente ao mercado externo.

4 As bases constitutivas da União Européia estâo consagradas nos seguintes tratados: o Tratado de Paris, que instituiu a Comunidade Européia do Carvão e do Aço (CECA), de 1951. e os Tratados de Roma, que instituiram a Comunidade Econômica Européia (CEE) e a Comunidade Européia da Energia Atônica (Euratom). de 1957. Tais tratados foram posteriormente alterados pelo Ato Único Europeu (1986). pelo Tratado da União Européia (Mastricht, 1992), pelo Tratado de Amsterdã (1997) e pelo Tratado de Nice (2001). Mais recentemente foi aprovada a Constituiçāo Européia pelo Parlamento Europeu. A União Européia tem cinco instituições. quais sejam: o Parlamento \&:uropeu, o Conselho da União Européia, a Comıssão Européia, o Tribunal de Justiça e o Tribunal de Contas.

s RENOLD. Marc-André. Les conflits de lois en droit antitrust. cit.. p. 140. Traduçào livre: "as duas noçōes sào a cara e a coroa da mesma moeda, a ação e o seu resultado" 
efeito, a toda aplicação extraterritorial (ação) deve corresponder um efeito extraterritorial (resultado). A diferença reside no fato de que enquanto a aplicação extraterritorial ocorre dentro do próprio Estado que reivindica a competência extraterritorial, o efeito dessa decisão manifesta-se no estrangeiro, no território de um Estado distinto do primeiro que. ao menos a princípio, não participou da aplicação daquela determinada lei. ${ }^{6}$

A capacidade de um Estado executar suas decisões fora de suas fronteiras depende de uma série de fatores. Fim primeiro lugar, está a importância do mercado do pais prejudicado para a empresa estrangeira. Ademais. uma empresa pode optar por cumprir voluntariamente decisões estrangeiras. ainda que o mercado desses países não seja de grande relevância para seus negócios, com o objetivo de cultivar a fama de pais cumpridor da legislação antitruste, o que the pode ser favorável em processos que enfrente em outras jurisdições (inclusive na sua).

Porém. pode não haver o cumprimento voluntário da decisão prolatada por um Estado estrangeiro pela empresa condenada. Nesse caso, na ausência de previsão de execução extraterritorial prevista em tratado internacional. será necessária a colaboração do Fstado estrangeiro. Contudo. como será visto adiante. este. sentindo sua soberania ameaçada, pode se recusar a colaborar ou mesmo impedir que a sentença estrangeira gere efeitos em seu país. Nesses casos. a eficácia da aplicação da lei antitruste a atos realizados fora da fronteira de um Estado dependerá. na prática. principalmente da existência de subsidiárias ou outro tipo de presença local que a empresa tenha nesse Estado. Nesse sentido, o enfoque tradicional de se considerar a matriz e a subsidiária entidades distintas para fins de aplicação antitruste foi sendo abandonado pelos países aos poucos, o que será visto oportunamente.

3. Jurisdição Extraterritorial e elementos de conexão

O termo "extraterritorialidade" pode levar a erro. dado que a jurisdição extraterritorial pode manifestar-se independentemente da natureza do elemento de conexão adotado (territorial ou não). Ėm matéria de defesa da concorrência, dois são os elementos de conexão que se destacam. O primeiro deles tem por base o princípio da territorialidade objetiva. Tal princípio estabelece uma relação entre o local do início da atividade, no exterior, c o local de sua consumação, no interior do Estado que visa ao

Nesse sentido, ver RENOLD, Marc-André. Les conflits de lois en droit antirmst. cit., p. 140. Por exenuplo, se os Estados Unidos aplicarem sua legislação antitruste a práticas lesivas da concorréncia ocorridas no interior da União Européia por sociedades comunitárias. a aplicação extraterritorial do direito norteamericano teve lugar nos Estados L'nidos, enquanto scus efeitos se farão sentir no mercado comunitáriu europeu. 
exercicio extraterritorial de sua jurisdição. A ocorrência parcial do ato no território do segundo Estado justifica a aplicação extraterritorial de suas leis.

$\mathrm{O}$ outro elemento comumente adotado pelos Estados para garantir a extraterritorialidade de suas leis antitruste tem por base a teoria dos efeitos territoriais. Essa teoria desenvolveu-se a partir do principio da territorialidade objetiva, sendo, contudo, mais abrangente que esta. Segundo a teoria dos efeitos territoriais, ou simplesmente teoria dos efeitos, ${ }^{\circ}$ se uma conduta, ainda que cometida inteiramente no exterior por empresas estrangeiras, gerar efeitos no território de um determinado Estado, este terá jurisdição sobre os responsáveis por tal conduta. Geralmente esses efeitos devem ser caracterizados como diretos, significativos e previsiveis para autorizar a jurisdição extraterritorial, requisitos esses propostos inicialmente pelos Estados Unidos e que vêm sido acolhidos por outras jurisdições.

$\mathrm{Na}$ grande maioria dos casos, a adoção do princípio da territorialidade objetiva ou dos efeitos territoriais levará ao mesmo resultado, o que faz com que alguns os tratem indistintamente. Isso porque o objetivo principal da política antitruste é a preocupação com os mercados internos e, portanto, o que irá autorizar o exercício da jurisdição sobre atos parcialmente ocorridos em um país que adote o princípio da territorialidade objetiva será a existência de efeitos diretos decorrentes dessa conduta no seu território. Com efeito, segundo importante lição de José Carlos de Magalhães, a "pedra de toque" do princípio da territorialidade objetiva "são os efeitos diretos do evento produzido dentro do território do Estado que. por isso mesmo, fica em posição legitima para conduzir a questâo dentro de sua esfera de competência" ${ }^{9}$

MAGALHÃES, José Carlos de. A aplicação extraterritorial de leis nacionais. Revistu Forense, Rio de Janeiro, v. 293, p. 95, jan./fev./mar. 1986. Em suas palavras. "O principio da territorialidade objetiva estabelece uma relação de causa e efeito no evento ocorrido parcialmente no exterior e parcialmente dentro do Estado, o que confere aos Estados envolvidos, em igualdade de condições, competência para regular o evento. bem assim. seus participantes. A justificativa aqui ć a ocorrência parcial do fato no território e. por via de conseqüência, do impacto social que o mismo causou. O Estado mais afetado pela ocorrència tem, preponderantemente, maior interesse em submetè-la à sua competência territorial. E é a maior ou menor intensidade du impacto no território dos Estados envulvidos que serve de elemento definidor das competências" Por sua importância. merece ser citado o caso Lotus, decidido pela Conte Permanente de Justiça Intemacional em 1927 (Caso S.S.Lotus, Série A, n. 10, p. 19, 1927). U caso envolveu o choque em alto-mar de um navio turco, Boz Koun, e um navio francês, Lótus, que ocasionou a morte de oito tripulantes turcos. A Turquia prendeu e processou o capitão do navio francês. $U$ caso foi levado à Corte Permanente de Justiça Internacional, que decidiu que a Turquia tinha u direito de exercer jurisdição sobre o capitão. uma vez que o local da consumação da conduta foi no navio de bandeira turca, que por ficção juridica. foi assimilado ao território turco. configurando importante caso de adoção do principio da territorialidade objetiva.

Ou ainda, como pretere MAGALHÃES, José Carlos de. A aplicação extraterritorial de leis nacionais. Revista Forense. Rio de Janeiro, v. 293, p. 94, jan./fev./mar. 1986. teoria dos impactos territoriais

Id. Ibid., p. 94. 
Por exemplo, imaginemos um cartel formado por empresas norteamericanas que combinam sua conduta na Suíça e vendem produtos a preços artificialmente elevados a consumidores da União Européia. De acordo com o princípio da territorialidade objetiva, a União Européia terá jurisdição sobre os infratores, uma vez que parte da conduta (a venda do produto) ocorreu no interior de seu território, causando danos aos seus consumidores. Da mesma forma, segundo a teoria dos efeitos, a União Européia terá jurisdição sobre a conduta, uma vez que esta teve efeitos em seu território (seus consumidores pagaram preços artificialmente elevados pelos produtos).

São raros os casos em que a escolha de um ou outro elemento de conexão levará a resultados opostos. Podem ser dados três exemplos. ${ }^{10} \mathrm{O}$ primeiro envolve a formação de um cartel de importação no pais A que afete o comércio de um certo produto produzido e ofertado pelo país $\mathrm{B}$. O segundo envolve a formação de um cartel de exportação no país A que afete o comércio de um produto com o país $\mathrm{B}$ (o ato de compra neste caso é feito ainda no país A). Finalmente, o terceiro exemplo envolve a restrição ilícita da produção de um produto por produtores de um país $\mathrm{A}$, criando escassez intencional do mesmo no país $\mathrm{B}$ e, possivelmente. ocasionando o aumento de seu preço nesse segundo país. Nesses três exemplos, toda a conduta foi planejada e cometida no exterior por empresas estrangeiras, não sendo possível que o país B exerça sua jurisdição extraterritorialmente com base no principio da territorialidade objetiva. Apenas se forem levados em conta os efeitos de tais condutas no país $\mathrm{B}$ que o mesmo estará autorizado a exercer sua jurisdição.

\section{Enfoque dos sistemas}

O entendimento da extraterritorialidade em defesa da concorrência evoluiu consideravelmente no curso do tempo. Serão vistas as posturas adotadas por Estados Unidos, União Européia e Brasil com relação à matéria. Uma análise mais detida do entendimento nos Estados Unidos é justificável por ser esse país o precursor do exercício da jurisdição extraterritorial ampla em matéria antitruste.

10 Nesse sentido, ver GRIFFIN, Joseph P. Extraterritoriality in U.S. and EU Antitrust Enforcemint. $6^{7}$ Antirnist Low Journal, v. 159, n. 187. 1999. 


\subsection{Estados Unidos ${ }^{11}$}

$60 \%$.

O primeiro caso que tratou da extraterritorialidade em direito da concorrência foi o American Banuna Co. v. United Fruit Co., ${ }^{12}$ julgado pela Suprema Corte dos Estados Unidos em 1909. ${ }^{13}$ A sociedade norte-americana American Banana alegou que sua plantação de bananas havia sido destruída por soldados da Costa Rica e Panamá instigados pela concorrente United Fruit, requerendo indenização. ${ }^{14} \mathrm{O}$ juiz do caso. Holmes, entendeu não ser cabível a aplicação extraterritorial pretendida. Em sua palavras: "The generul and almost universal rule is that the character of an act as lawful or unlawful must be determined wholly by the law of the country where the act is done" 15

Assim, como o delito não havia sido cometido nos Estados Unidos. este país não teria jurisdição sobre o caso, nos termos do princípio da lex loci delicti commissi. Ademais, considerando que os atos do réu não eram ilegais na jurisdição onde foram praticados, não poderiam ser punidos por outros Estados. ${ }^{16}$ Essa aplicação territorial da legislação antitruste ficou conhecida como vested rights theory. Porém. a

1! Os Estados Unidos têm um sistema peculiar de defesa da concorrência. E o Poder Judiciário que decide $\mathrm{em}$ instância final acerca da aprovação de uma determinada operação que tenha sido apontada com putencialidade de causar efeitos anticoncorrenciais no mercado e da condenação relacionada à prática de condutas anticompetitivas. O Poder Judiciário só altuará mediante provocação e pode ser acionado tanto pelos órgãos antitruste federais Antitrust Division of the United States Department of Justice - DOJ - e o Bureau of Competition of the Federal Trade ('ommission - FTC) quanto pelos Stutes Attorneys General ou terceiros prejudicados.

1: Americun Bununa Cu. v: United Fruit Co., 213 US 347 (1909).

: Para uma análise pormenorizada da aplicação extraterritorial da legislação antitruste norte-americana até a década de 70. ver Hendrik Zwarensteyn. Some aspects ofthe extraterritorial reach ofihe American antitrust laws, Deventur: Fred B. Rothman \& Co., 1970.

is Nos Estados Unidos é devido a titulo de sucumbência em ações antitruste privadas três vezes o valor do dano (treble damages). A ação baseava-se na então Section 7 do Sherman Act, hoje substituida pela Section 4 do Clayton Act.

American Banana Co. v. United liruit Co., cit.. 356. E continua "... For another jurisdiction. if it should happen to lay hold of the actor. to treat him according to its own notions rather than those of the place where lie did the acts, not only would be unjust, but would be an interjerence with the authority of another sovereign. contrany to the comity of nutions, which the other state concerned justly might resent". Em tradução livre: "A regra geral, quase universal, è de que o julgamento de um ato como legal ou ilegal deve ser determinado totalmente pela lei do país onde tal ato foi praticado... Para outra jurisdição, se acontecer de aplicar a lei a um determinado agente, de ele ser tratado de acordo com suas próprias noçōes ao invés daquelas do lugar em que a conduta foi comelida, isso seria não apenas injusto, mas significaria uma interferência na decisão de outra soberania, o que é contrário à cortesia entre as naçōes, podendo levar a um ressentimento por parte do outro Estado envolvido"

A decisão do Juiz Holmes desagradou muitos doutrinadores. havendo inclusive aqueles que o acusaram de estar sofrendo de uma esquizofrenia juridica (ver S. Timberg, "Extraterritorial Jurisdiction under the Sherman Act" II The Record of the Association of the Bar of the City of New York 101 (1956) apud Hendrik Zwarensteyn, Some aspects ofthe extruterritorial reach ofthe Americun untitrust laws. cit... p. 124). 
adoção do princípio da lex loci delicti commissi trouxe algumas dificuldades de interpretação. O que seria considerado o lugar do delito? O que abrangeria o delito? No caso American Banana, apesar de toda a conspiração ter sido armada na sede da United Fruit em Nova lorque, o juiz Holmes considerou que o que importava era apenas o local da destruição da plantação de bananas. Cerca de vinte anos depois, no julgamento de um caso de circunstâncias similares caso Sisal Sales 17 a Suprema Corte dos Estados Unidos chegou a um resultado oposto por meio da interpretação do que seria considerado o lugar do delito. Por essas limitações, o princípio da territorialidade foi sendo flexibilizado aos poucos até ser abandonado por completo nos Estados Unidos em $1945 .^{18}$

Nesse ano foi julgado o caso United States v. Aluminum Co. of America (Alcoa $)^{19}$ pelo Segundo Circuito. O caso envolveu a formação de um cartel por um grupo de sociedades não norte-americanas produtoras de lingotes de alumínio. A Alcoa, sociedada norte-americana, não integrava o cartel, mas seus acionistas controlavam a Aluminium Limited, sociedade canadense participante do cartel. ${ }^{20} \mathrm{O}$ juiz do caso, Learned Hand, sentenciou que o Sherman Act seria aplicável a acordos ocorridos no exterior se eles tivessem intenção de gerar efeitos no mercado dos Estados Unidos ou em seu comércio exterior e se de fato tivessem gerado. ${ }^{21}$ Essa teoria, conhecida como "effects theory" foi acolhida pela Suprema Corte dos Estados Unidos no julgamento do caso Continental Ore Co. v. Union Carbide \& Carbon Corp 22 em 1962.

A orientação estabelecida no caso Alcoa foi parcialmente questionada em 1976 no julgamento do caso Timberlane Lumber Co. v. Bank of America National Trust \& Savings .Association. ${ }^{23}$ Neste caso, a empresa norte-americana Timberlane, que tinha como principal negócio a compra de madeira no exterior para posterior venda nos

17 United States ı: Sisal Sales Corporation et ai.. TIA U.S. 26847 S. Ct. 592 (1927). No caso. um grupo de banqueiros e importadores norte-americanos de sisal decidiu monopolizar a totalidade do mercado mexicano de exportação de sisal, principalmente a exportação para us Estados ('nidos, graças à permissão da legislação mexicana adotada ad hoc para este monopólio.

18 Esse novo posicionamento está ligado à mudança na politica exterior dos Estados Unidos, que havia decidido sair do isolacionismo tradicional para incorporar o papel de lider mundial. Nesse sentido, ver ZANETTIN, Bruno. Cooperation hetween antitrust agencies at the International levei. Oxford, Portland: Hart Publishing, 2002. p. 10.

19 United States v. Aluminum Co. of America, 148 F.2d 416, 448 (2"d (irc. 1945).

20 Como será visto adiante, os Estados L'nidos, a exemplo de outras jurisdições, considcram matriz, e controlada entidades únicas para fins de aplicação antitruste. Nesse caso. os Estados Unidos indicou no pólo passivo da ação uma empresa nacional que, apesar de não integrar o cartel, controlava uma empresa canadense participante do mesmo.

21 Unired States v. Aluminum Co. of America, cit., p. 443-44.

22 Continental Ore Co. v. Union Carbide \& Carbon Corp., 370 U.S. 690, 704-05 (1962).

23 Timberlane Lumber Co. v. Bank of America National Trust \& Savings Association. 549 F.2d 597 (9n Circ. 1976). Barry E. Hawk, United States. Commom Market and International Antitrust: A Comparative Guide. 2 ed.. 1985 \& Supp. 1989, Englewood Cliffs: Prentice Hall Law \& Busincss, p. 118 , chega a afirmar que a aplicação moderna do Sherman Act a condutas estrangeiras deu-se a partir de 1976, com base nesse julgado. 
Estados Unidos, alegava que o Bank of America, por meio de diversas manobras, havia prejudicado a obtenção de madeira por parte da empresa em Honduras. requerendo, assim, sua condenação nos termos do Sherman Act.

Ao julgar o caso. o tribunal considerou que a teoria dos efeitos estava incompleta. uma vez que não considerava os interesses das demais nações e, assim, adotou um teste para determinar se um país deveria exercer sua jurisdição extraterritorialmente. Três requisitos deveriam ser preenchidos: ${ }^{24}$ (i) o ato deve gerar algum efeito - real ou pretendido no comércio dos Estados Unidos; (ii) o ato deve causar violação evidente ao Sherman Act; e (iii) os interesses dos Fstados Unidos devem ser suficientemente fortes diante dos interesses das demais nações (em obediência ao princípio da cortesia internacional). ${ }^{25}$

Fssa teoria ficou conhecida como balancing ofinterests ou jurisdictional rule ofreason. A decisão Timberlane foi alvo de críticas uma vez que, no geral, há uma tendência natural dos juizes de dar maior peso aos interesses nacionais que aos dos demais paises. ${ }^{26}$ Por isso, não houve consenso nas Cortes Federais quanto à aplicação da teoria do balancing of interests. Os Circuitos Terceiro, ${ }^{2-}$ Quinto ${ }^{28}$ e Décimo ${ }^{29}$ acolheram o entendimento fixado no caso Timberlane, enquanto que os Circuitos Sétimo e D.C. questionaram sua validade.

Em 1982, o Congresso dos Estados Unidos manifestou sua posição em relação à teoria dos efeitos com a edição do Foreign Trade Antitrust Improvement Act

24 No caso concreto. o tribunal concluiu pelo declínio do exercício da jurisdição extraterritorial por não estarem preenchidos todos os requisitos do teste. Entre outros argumentos, o tribunal considerou que os efeitos no comércio dos Estados Únidos não foram significativos e que era considerável a possibilidade de haver um conflito com a politica econômica e comercial de Honduras.

25 Com relação à terceira exigĉncia, o tribunal considerou que scte deveriam ser os fatores a serem considerados, quais sejam: (i) o grau de conllito com política ou legislação estrangeiras: (ii) a nacionalidade das partes e a lucalizaçăo dos seus principais centros de negócios; (iii) a probabilidade de cumprimento da decisão dos países envolvidos; (iv) a impurtância relativa dos efeitos do ato nos Estados Unidos se comparados com os efeitos em outros paises; (v) a avaliação da existéncia de propósitos explicitos de prejudicar ou afetar o comércio norte- americano: (vi) a previsibilidade de tais efeitos; e (vii) a importância relativa das violações nos Estados Unidos se comparadas com os demais paises. Timberlane Lumber Co. v. Bank of America National Trust \& Savings Association, cit.. 614.

26 Nesse sentido, ver Aidan Robertson \& Marie Demetriou. "But that was in another country...: The extraterritorial application of US antitrust laws in the US Supreme Court" in International and Comparative Low' Quarlerly. 43, part. 2, Glasgow, Bell and Bain Lid., 1994.

27 O Terceiro Circuito, ao adotar o teste em decisão no caso Mannington Mills. Inc. v. Congoleum Corp., 595 F.2d 1287. 1297-98 ( $3^{\text {rd }}$ Cir. 1979) adicionou os seguintes fatores àqueles sete a serem considerados no que se refere ao terceiro requisito do teste Timberlaine. (i) a existência de decisões connlitantes; (ii) a possibilidade rcal de execução extraterritorial; (iii) o nivel de aceitação nos Estados Unidos de decisão similar proferida por Estado estrangeiro: $c$ (iv) a existência de um tratado internacional com os paises afetados que trate da questão.

${ }_{28}$ American Ricc, Inc. v. Arkansas Rice Growers Co-op. Ass in. 701 F.2d 408, 413 (5' Cir. 1983).

29 Montreal Trading v. Amax, 661 F.2d 864 (10 ${ }^{\text {th }}$ Circ. 1981), cert. denied, 455 U.S. 1001, 102 S.C.1. 1634 (1982). 
(FTALA). ${ }^{30} \mathrm{O}$ Congresso entendeu que só poderá haver exercício extraterritorial da jurisdição em matéria antitruste se determinada conduta estrangeira tiver gerado efeito direto, significativo e razoavelmente previsivel ("direct, substantial, and reasonably foreseeable effecf') no comércio dos Estados Unidos, ${ }^{31}$ sem fazer menção à necessidade de se considerar a cortesia internacional quando da aplicação dessa teoria.

Em seguida, em 1987, foi editado o Restatement (Third) of Foreign Relations Law of the United States ${ }^{32}$ que prevê que os Estados Unidos terão jurisdição sobre acordos concluídos no exterior que tiverem como objetivo principal interferir em seu comércio e se gerarem algum efeito no mercado. A compilação prevê, ainda, a jurisdição sobre qualquer outro acordo que tenha efeito substancial no comércio dos Estados Unidos se o exercício da jurisdição for razoável. Note-se que, de acordo com a compilação, condutas cometidas no estrangeiro que tenham por efeito criar barreiras de acesso a mercado aos produtores norte-americanos estão sujeitas à legislação antitruste dos Estados Unidos.

Em 1993, a Suprema Corte dos Estados Unidos, em uma decisão controvertida (cinco votos a quarto) no julgamento do caso Hartford Fire Ins. Co. v. Califórnia ${ }^{33}$ considerou que o Sherman $\mathrm{Act}$ é aplicável às condutas estrangeiras que tenham produzido efeitos significativos nos Estados Unidos. ${ }^{34}$ A Corte concluiu que a cortesia internacional apenas deve ser considerada quando verdadeiramente existir um conflito entre a lei nacional e a estrangeira. ${ }^{35}$ No caso concreto, a Corte sustentou que os réus deveriam sujeitar-se ao Sherman Act uma vez que deveriam cumprir tanto as leis dos Estados Unidos quanto as da Inglaterra. ${ }^{36} \mathrm{O}$ juiz vencido, Scalia, criticou a decisão, sustentando que esse posicionamento prejudicaria o relacionamento dos Estados Unidos com seus parceiros comerciais. ${ }^{37}$

30 15 U.S.C. $\$ 6$ a.

31 Essc efeito deve também dar lugar a uma ação nos termos do Sherman Acl. Cf. 15 U.S.C. § 6a.(2).

32 Apesar de não ser editado por uma fonte governamental, mas sim pelo American Law Institute, esta compilação da lei e politica dos Estados Unidos é altamente respeitada no país. A compilação anterior data de 1965.

33 Hartford Fire Ins. Co. v. Califórnia, 509 U.S. 764 (1993). A ação havia sido movida por dczenove State Attorney General. juntamente com uma sćrie de litigantes privados, contra empresas do ramo de seguros estabelecidas em Londres que teriam alterado os termos da previsão dos seguros, prejudicando clientes norte-americanos.

34 Hariford Fire Ins. Co. v. California, cit., 796.

35 Id. Ibid., 798.

36 Hartford Fire Ins. ('o. v. California, cit., 799: "no conflict exists between laws of United States and foreign state. for purposes of principies of international comity. where a person subject to regulations by two states can comply with the law ofboth" Em tradução livre: "não há conflito entre as leis dos Estados Unidos e as estrangeiras, sob o aspectu do principio da conesia internacional, quando uma pessoa sujeita a ambas as leis puder cumprir com as determinações de ambas".

Cl. Aidan Robertson \& Marie Demetriou. "But that was in another country...", cit., o juiz Scalia afirmou: "that breathtakingiy broad proposition (...) will bring the Sherman Act and other law's into sharp and 
Com o fim de tornar claro seu posicionamento sobre a questão, em abril de 1995, a FTC e o DOJ emitiram o Antitrust Enforcement Guidelines for International Operations (Guidelines), que fixa critérios para determinar se um órgão terá competência para investigar atos cometidos fora de seu território. Entre outros critérios, deve-se comparar a importância relativa do ato para os Estados Unidos e os demais países afetados pelo ato. analisar a existência de propósitos explícitos de prejudicar ou afetar o comércio norte-americano e avaliar a efetividade de repressão no pais estrangeiro (o que nos remete novamente à cortesia internacional). Importante notar que as Guidelines ressaltaram em seu texto a aplicação da legislação antitruste dos Estados Unidos a condulas que impeçam o acesso de empresas norte-americanos a mercados externos, ${ }^{38}$ em linha com o previsto pelo Restatement (Third) of Foreign Relations Law. ${ }^{39}$

Quanto às previsões de cunho penal da legislação antitruste dos Estados Unidos, o Primeiro Circuito entendeu, em decisão proferida no caso United States 1 : Nippon Paper Industries Co., ${ }^{10}$ que as mesmas são aplicáveis aos infratores estrangeiros tais como as previsões civis do Sherman Act."

No que se refere à possibilidade de os Estados Unidos excrcerem jurisdição sobre a matriz estrangeira por meio de subsidiária local, doutrina ${ }^{4 ?}$ e jurisprudência tem indicado que a resposta é positiva. Em Kramer Motors v. British Leylana ${ }^{43}$ decidiu-se que, para tanto, era necessário comprovar que a matriz tinha interferência nas atividades da subsidiária. Em 1984, com o julgamento pela Suprema Corte do caso Copperweld Corp. 1: Independence Tuhe Corp. ${ }^{+4}$ foi lançada a doutrina

unnecessany conflict with the legitimate interests of (...) our closest trading partners" Em tradução livru: "essa proposta ampla e impensada (...) levará o Sherman Act e outras leis a conflitos desnecessários com interesses legitimos de (...) nossos parceiros comerciais mais proximos"

38 U.S. Department of Justice: The Federal Trade Commission, Antitrust Enforcement Guidelines for International Operations. [s.l., s.n.], 1995, ponto 3.122 "Jurisdiction in Cases Under Subsection (B) of the FTAIA"

j* As Guidelines trazem uma série de análises por meio de excmplos ilustrativos. Por sua expressividade, analisemos o primeiro deles. O caso trata de quatro empresas estrangeiras que oferecem seus produtos nos Estados Unidos por meio exclusivamente de exportações e que passam a aumentar o preço do produto artificialmente por meio de um cartel. As vendas dessas empresas representam um percentual significativo se comparado com as vendas totais do produto no pais. As Guidelines concluem que esse caso está sujuito à jurisdição dos Estados Unidos, haja vista os efeitos produzidos no seu território.

so Unired States v: Nippon Paper Industries Co. 109 F.3d I (1. Cir. 1997). Neste caso, a conduta anticoncorrencial de fixação de preços teve lugar inteiramente no Japão. com geração de efcitos nos Estados Unidos. A decisão final ressaltou que a conduta cometida pelos individuos condenados era ilegal tanto nos Estados Unidos quanto no Japào.

4 Sobre, ver James Sicilian \& Philip S. Wellman. "The Fxtraterritorial Application of the US Antitrust to Criminal Conspiracies" in European Competition Law' Revicu: 151. 1988.

42 Ver. p. ex.. Phillip Areeda \& Louis Kaplow, Antitrust analysis: problcms. text, cases. Boston: Littlc-Brown \& Co.,4.ed.. 1988. p. 155 e ss.

4) Kramer Molors v. British Leyland. 628 F2d. 1175 (9 $9^{\text {th }}$ Cir.), cert. Denied, 449 U.S. 1062, 101 S.Cl. 785 (1980).

th Copperweld Corp. 1: Independence Tube Corp.. 467 U.S. 752, 104 S.CT. 2731 (1984). 
Copperweld, segundo a qual a matriz e sua subsidiária integral devem ser tratadas como entidades únicas para fins de aplicação da legislação antitruste em vista da unidade de interesses de ambas. Isso porque a decisão de uma empresa de estabelecer uma subsidiária está ligada a questões tributárias e outras questões que pouco tem a ver com o direito antitruste. No caso da subsidiária não ser integral, há que considerar se a matriz detém o seu controle. Em caso positivo. o exercício de jurisdição sobre a matriz ustrangeira por meio da subsidiária local estará autorizado. ${ }^{45}$ Por outro lado, se a empresa estrangeira não detiver o controle da empresa localizada nos Estados Unidos, não interferindo de maneira decisiva no processo de condução dos seus negócios, a doutrina Coopperweld não deverá sưr aplicada. ${ }^{46}$

Com relação à imunidade de jurisdição sobre outros Estados, os Estados Unidos vêm seguindo, desde 1976, o Foreign Sovereign Immunities $A c t,{ }^{+7}$ que garante imunidade antitruste para os atos de um terceiro Fstado cometidos como ente público soberano ("governmental actions"), mas não para aqueles atos cometidos como se particular fosse ("commercial actions"). ${ }^{48}$

Finalmente, no tocante à possibilidade de particulares estrangeiros ingressarem com uma ação privada nos Fstados Unidos pleiteando três vezes o valor do dano $\mathrm{cm}$ virtude de conduta anticoncorrencial (Ireble damages), o entendimento da Suprema Corte, fixado recentemente no caso F. Hqffmann-La Roche Ltd. v. Empagran S.A. et ai., ${ }^{49}$ é restritivo. O caso envolvia a fixação de preços por produtores de vitaminas

45 Nesse sentido, Rohlfing v. Manor Care. Inc., 172 FRD 330, (N.D. III 1997); Seabury Management. Inc. v: Professional Golfers Association of America. Inc.. 878 F.Supp. 77 I (D. Md. 1994); Rosen v. Hyundai Group (Korea), 829 F.Supp. 41 (E.D. N.Y. 1993).

46 Cf. Herbert Hovenkamp, Federal Antirtust Policy - The Law of Competition and its practice, $2^{a}$ ed., St. Paul: West Group. 1999, pp. 186-190.

47 28 U.S.C.A. $\$ 1602$ e ss.

48 No caso Imernational Assn. of Machinists \& Aerospace Workers v. Organization of Petroleum Exporting. Countries, 649 F.2d 1354 (9th Circ.1981), cert. denied, 454 U.S. 1163.102 S.Ct. 1036 (1982), foi movida uma ação com base no Sherman Acl contra os membros da OPEC por fixação de preço do petróleo e seus derivados. $O$ tribunal entendeu. entre outros argumentos, que política rilacionada a recursos naturais era central para a suberania dos paises membros da OPEC e que aquelas atividades eram governamentais e não comerciais, estando, portanto, imunes à legislação antitruste. Em Oubboard Marine Corp. v. Pezelel, 46 I F.Supp. 384 (D.Del. 1978), o tribunal entendeu que uma organização governamental polonesa ativa na comercialização de equipamentos de golfe (golf carts) não estava imune à legislação antitrusic norteamericana, em vista do caráter comercial de suas atividades.

49 F. Hoffinam-La Roche Lıd v. Empagran S.A. et al., 124 S. Ct. 2359 (2004). A decisão, unânime, pôs fím à divergência existente entre o Quinto Circuito. de um lado, e o Segundo e o D.C. Circuitos de outro. No caso Den Norske Stats Oljeselskap As v. HecreMac Vof 241 F.3rd 420 (5" Cir., 2001), uma empresa petrolifera da Noruega visava à condenação nos termos do Sherman Act de grandes petroleiros que teriam artificialmente inflado os preços dos seus serviços ne Mar do Norte e no Golfo do México por meio de uma conspiração, visando à obtenção de indenização. O Quinto Circuito decidiu que os Estados Unidos não tinham jurisdição sobre o caso. ainda que o mesmo tunha resultado em preços mais elevados do petróleo no pais. Isso porque os danos que a empresa da Noruega afirmou cir sofrido nào decorreram dos efeitos da conduta no mercado doméstico nurte-americino. mas derivaram diretamente de conduta 
que levou ao aumento de preços do produto nos Estados Unidos e, de forma independente, em outros países (cartel internacional). Distribuidores de vitaminas da Ucrânia, Austrália, Equador e Panamá ingressaram com ação nos Estados Unidos visando à indenização. A Suprema Corte concluiu, observando o princípio de nãointerferência do direito internacional público, que os Estados Unidos não eram competentes para conhecer aquele pedido de indenização uma vez que os danos alegados não decorreram diretamente dos efeitos da conduta nos Estados Unidos. Com efeito, decisão em sentido diverso faria com que partes estrangeiras ingressassem com ações de indenizações nos Estados Unidos em uma escala nunca desejada pelo Congresso norteamericano - reflexo do intemational fórum shopping, ${ }^{50} \mathrm{em}$ vista da relativa agilidade do Judiciário norte-americano, se comparado com o de outros países, e da previsão de treble damages.

Concluindo, os Estados Unidos passaram da adoção do princípio da territorialidade estrita para a teoria dos efeitos, muitas vezes adotada de forma agressiva, sem considerar por completo o interesse dos demais países envolvidos. Com o precedente lançado pela Suprema Corte no caso Hartford Fire, o papel da cortesia internacional, antes ressaltado no caso Timberlane, foi reduzido, devendo ser observado apenas quando houver um conflito direto entre leis nacionais e estrangeiras. Deve-se dizer que grande parte dos países discorda explicitamente do amplo escopo extraterritorial da lei de defesa da concorrência dos Estados Unidos, principalmente em vista de que nesse país são devidos três vezes o valor do dano em ações antitruste privadas (treble damages) e em vista do caráter penal de sua legislação antitruste. $\mathrm{O}$ posicionamento adotado no caso Empagran apenas limita, em termos, que partes estrangeiras busquem indenização por danos anticoncorrenciais em ações privadas no país, mas não significa que o país restringiu o âmbito extraterritorial de suas leis a

ocorrida fora dos Estados Unidos. De forma oposta decidiu o Segundo Circuito no caso Kruman $v$. Christie's International PLC. 284 F.3d 384 ( $2^{\text {nd }}$ Cir. 2002). Neste, partes estrangeiras visavam a obter indenização por danos causados pela fixação de preços no mercado de leilão de peças de arte por parte da Christie's e Sotheby's. O tribunal concluiu que, como a conduta havia também gerado efeitos nos Estados Unidos, a indenização era devida. Essc posicionamento havia sido adotado pelo Circuito D.C. no caso Empagran antes do mesmo ser remetido à Suprema Corte. Com a decisão da Suprema Corte, a divergência fica superada, uma vez que sua decisão é vinculativa para todas as futuras decisões proferidas pelos tribunais e juizes norte-americanos.

30 O desejo da Suprema Corte de evitar que os Estados Unidos sejam alvo preferencial do intemational fórum shopping não está presente apenas no campo antitruste. Logo após a decisão Empagran, a Suprema Corte entendeu que o Alien Tort Statute, diploma norte-americano que disciplina a responsabilidade civil relativa a fato ilícito reclamada por estrangeiro, não enseja ações nos Estados Unidos por todas as violações de direitos humanos ocorridas no exterior caso Sosa v. Alvarez-Machain, 124 S. Ct. 2739 (2004). 
condutas e estruturas anticoncorrenciais (reais ou potenciais) que causem efeitos nos Estados Unidos.

\title{
4.2. União Européia
}

O art. $81, \S 1^{\circ}$ do Tratado de Roma ${ }^{51}$ determina que são incompatíveis com o mercado comum e proibidos todos os acordos entre empresas, decisões de associações de empresas e práticas concertadas que sejam suscetíveis de afetar o comércio entre os Estados-membros e que tenham por objetivo ou efeito impedir, restringir ou falsear a concorrência no mercado comum. Os tribunais europeus e a Comissão Européia ${ }^{52}$ foram aplicando essa determinação a condutas praticadas por empresas estrangeiras que afetassem o mercado comunitário com base em diferentes teorias.

Na decisão proferida no acórdão Béguelin ${ }^{53}$ em 1971, o Tribunal de Justiça das Comunidades Européias (TJCE), ${ }^{54}$ consagrou pela primeira vez o critério da territorialidade objetiva com o fim de determinar o campo de aplicação das normas concorrenciais comunitárias. Segunda esta decisão, as normas concorrências comunitárias deverão ser aplicadas toda vez que um acordo for aplicável no interior do mercado comum, independente das partes envolvidas estarem ou não situadas dentro da Comunidade:

\begin{abstract}
2. Competition - Cartéis - Participation in an agreement by an undertaking situate in a thirá country Application of the prohibition in article 85 (I) - conditions 2. (A) if the agreement is operative on the territory of the common market, the fact that one of the undertakings which are parties to it is situated in a third country does not prevent the application of article 85 of the EEC treaty. ${ }^{55}$
\end{abstract}

S1 Tratado que instituiu a Comunidade Européia, de 25 de março de 1957. versão consolidada.

52 A Comissão Européia é o órgão executivo da Comunidade. A Comissão é a responsável por decidir $\mathrm{cm}$ caráter definitivo na esfera administrativa todas as yuestões relacionadas ao controle de estruturas e condutas que tenham dimensão comunitária. A decisão da Comissão está sujeita ao controle jurisdicional do Tribunal de Primeira Instância das Comunidades Européias e do Tribunal de Justiça das Comunidades Européias.

53 Processo 22/71, Béguelin Import Co. v S.A.G.L. Import Export. 1971; ECR 949.

s4 O TJCE é o órgão jurisdicional comum às três comunidades européias. Como intérprete final du Direito Comunitário, contribui à unificaçāo do mesmo. É um tribunal de recurso frente às decisões do Tribunal de Primeira Instância das Comunidades Européias. Com a ratificação da Constituição Européia pelos Estados Membros c após cumpridos os requisitos necessários para sua entrada em vigor, passará a se chamar "Tribunal de Justiça da União Européia" (TJUE).

5s Em tradução livre: "2. Concorrência - Cartéis Participação em um acordo por meio de um compromisso tomado em um terceiro pais - Aplicação do artigo 85 (1) - Condições. 2. (A) Se o acordo é operacional no território do mercado comum. o fato de que um dos acordos foi tomado pelas partes em um terceiro pais não impede a aplicação do artigo 85 do Tratado das Comunidades Européias" 
Em 1988, o TJCE julgou o caso Woodpulp, ${ }^{\varsigma 6}$ condenando fabricantes de celulose finlandeses, suecos, canadenses e norte-americanos por formação de cartel que havia prejudicado o comércio comunitário. ${ }^{57}$ As empresas haviam recorrido da decisão da Comissão ao TJCE alegando que a União Européia não tcria jurisdição sobre eles. configurando-se uma violação do dever de não-intervenção previsto no direito internacional público. O TJCE rejeitou tal argumentação, com base no que segue:

The producers in this case implemented their pricing agreement within the Common Market. (...) Accordingly the Community's jurisdiction to apply its competition rides to such conduct is covered by the territoriality principie as universally recognized in puhlic international law. ${ }^{58}$

Assim, a venda de produtos a consumidores situados na União Européia por empresas estrangeiras é suficiente para justificar a jurisdição do bloco, sendo irrelevante para esse propósito se a venda se deu de forma direta ou indireta. Essa teoria ficou conhecida como implementation doctrine, que tem por base o princípio da territorialidade objetiva.

A tcoria dos efeitos foi adotada pela Corte de Primeira Instância das Comunidades Européias ${ }^{59}$ (TPICE) no caso Gencor, ${ }^{60}$ que sentenciou que a jurisdição extraterritorial da União Européia justifica-se perante o direito internacional público toda vez que seja previsível que um ato de concentração traga efeitos imediatos e significativos no mercado comum. Os critérios de "previsibilidade" "efeitos imediatos" e "efeitos significativos" devem ser verificados caso a caso. A sentença ressaltou que a adoção da teoria dos efeitos não significa o abandono da implementation doctrine, em vista da complementaridade de ambas. Apesar de esse último julgamento tratar de um ato de concentração, deve-se considerar que a teoria dos efeitos é igualmente aplicável a condutas anticoncorrenciais, uma vez que as questões jurisdicionais a serem analisadas são basicamente as mesmas.

s6 Casos conjuntos 89, 114, 116-117 c 125-129/85. A. Ahlström Osakeyhtio and Others v. Comission (Woodpulp 1). 1988, ECR 5193.

57 Decisão n. 85/202, de 19 de dezembro de 1984, OJ (1985) L 85/1.

58 Em tradução livre: "Os fabricantes implementaram seus acordos de preço dentro do mercado comum. (...) Nesse sentido, a jurisdição da Comunidade para aplicar suas regras de defesa da concorrência para tal conduta é coberta pelo principio da territorialidade, tal como reconhecido no direito internacional público"

59 O TPICE foi criado pela Decısão do Conselho das Comunidades Européias $n^{\circ} 88 / 591$, de 24 de outubro de 1988, e examina em primeira instância, cntre outros, os recursos apresentados contra uma instituição da Comunidade por pessoas físicas ou juridicas e que concernem à aplicação de regras da concorrència. Contra suas decisões, cabe recurso ao TJCE.

60 Caso T-102'96 Gencor Lid v. Comission. 1999, 4 CMLR 971. 
Surge a questão se o TJCE adotará expressamente a teoria dos efeitos, visto que a decisão acima citada é oriunda do TPICE. A tendência é que isso ocorra, mas a verdade é que a distinção prática entre a teoria dos efeitos e a teoria da implementação é limitada, como visto acima, o que tira a relevância da discussão relativa a ısse ponto. ${ }^{61}$ O Procurador Geral da então Comunidade Européia, M. Darmon, ${ }^{62}$ afirmou expressamente que a teoria da implementação pauta-se na teoria dos efeitos, uma vez. que a justificativa final é a presença de efeitos diretos, significativos e previsíveis do ato no mercado comum. Ainda, nas palavras do então Assistant Attorney General do Departamento de Justiça dos Estados Unidos: "European Union's is very dose to, if not indistinguishable from, the so-culled "effects test as appliedby U.S. courts"

$A$ Comissão Européia tem ido mais além e expressado seu desejo de aplicar extraterritorialmente a legislação comunitária de defesa da concorrência não só a práticas estrangeiras cometidas em parte no interior do bloco, mas também a práticas estrangeiras que impeçam empresas comunitárias de terem acesso a terceiros mercados, nos moldes dos Estados Unidos. ${ }^{63}$

No que se refere ao alcance da matriz estrangeira por meio de atos cometidos pela subsidiária comunitária, a Comissão e o TJCE entendem que a resposta é positiva. No julgamento do caso Dyestujfs, ${ }^{64}$ o TJCE entendeu que é atribuída ao grupo econômico situado fora da União Européia a conduta de sua subsidiária comunitária. Tratava-se de um cartel de fabricantes de tintas que fixava preços de uma série de produtos vendidos no mercado comum. A empresa inglesa Imperial Chemical Industries (ICI) fazia parte do cartel e atuava de forma indireta no mercado comunitário, por meio de suas subsidiárias (à época. o Reino Unido ainda não era membro da União İuropéia). A Comissão Européia decidiu punir a empresa inglesa, que apelou para o TJCE

${ }_{61}^{61}$ Joseph P. Griffin, "Extraterritoriality in L.S. and EU Antitrust Enforcement". cil.: ".Iny practical importance of the distinction between anti-competitive conduct outside the EU 'implemented' in the Common Market and the 'effect' of such conduct in the Common Market likely is limited to a few. rare situations". Em tradução livre: "Qualquer impontância prática da distinção entre condutas anticompetitivas ocorridas fora da União Européia e implementadas no Mercado Comum e os efeitos de tais condutas no Mercado Comum está limitada a raras é poucas situações"

62 Parecer de 25 de maio de 1988 , parágrafos 47 e ss.

63 Karel Van Miert, "Analysis and Guidelines on Competitive Policy, Address at Royal Institute of Int'I Affairs", London (May 11, 1993), apud Joseph P. Griffin, "EC and U.S. Extraterritoriality: Activism and Co-operation", Fordham International Law Journal, 1993, então Comissário da Direção da Concorrência, indicou que a Comissão Européia "needs to ensure (...) (ii) that anticompetitive pracrices in third markets do not preveni EC companies having access to those markets... The Commission will not hesitate to use its powers wliere necessary to preserve undistorted competition inside the EC and mark t access outside" Em tradução livre: "precisa garantir (...) (ii) que práticas em terceiros mercados não impeçam empresas da Comunidade Européia de ingressar nesses mercados. A Comissão não hesitará em usar seus poderes toda vez que necessário para preservar a concorrência dentro da Comunidade Europèia e para garantir o acesso a mercados estrangeiros"

at Processo 48/69, ICI v. (omission (Dyestujfs). 1972, ECR 619. 
argumentando que não poderia ser responsabilizada pela conduta de suas subsidiárias. O tribunal rejeitou tal argumento, sentenciando que o fato da subsidiária ter uma personalidade jurídica distinta da matri\% não é suficiente para excluir a possibilidade de imputar sua conduta à sua controladora, enfatizando-se a unidade da conduta no mercado para os fins de aplicação de normas concorrenciais. Essa doutrina ficou conhecida como economia entity doctrine ou group economic unit doctrine. Esse posicionamento foi reafirmado pelo TJCE no caso Woodpulp referido acima. ${ }^{65}$

Essa doutrina foi suavizada com o caso Viho, ${ }^{6 \hbar}$ com a adoção da intraenterprise doctrine. De acordo com esta, o referido art. $81, \S \mathrm{I}^{\circ}$, não se aplica aos acordos intra-empresa ou práticas envolvendo a matriz e suas subsidiárias se o grupo econômico é estruturado de tal forma que as subsidiárias têm liberdade para determinar seu curso de ação no mercado.

Pode-se concluir que o TJCE tem aos poucos procurado se alinhar com a teoria dos efeitos defendida pela Comissão, seguindo posicionamento dos Estados Unidos. Ainda que hoje o TJCE. e a Comissão justifiquem o exercício extraterritorial da jurisdição da Comunidade com base em diferentes teorias, isso não leva a decisões divergentes na grande maioria dos casos, o que faz com que, nos casos controversos, a jurisdição da União Furopéia seja confirmada em sede recursal. Conclui-se que, a exemplo dos Estados Unidos, houve aos poucos um alargamento do exercício da jurisdição extraterritorial.

\subsection{Brasil}

A lei de defesa da concorrência brasileira (Lei n. 8.884, de 11 de junho de 1994) prevê explicitamente sua aplicação extraterritorial. O âmbito da aplicação da lei é fixado no caput do seu art. $2^{\circ}$ que determina, in verbis:

Art. $2^{\circ}$. Aplica-se esta Lei, sem prejuizo de convenções e tratados de que seja signatário o Brasil, às práticas cometidas no todo ou em parte no território nacional ou que nele produzam ou possam produzir efeitos.

Uma análise do caput desse artigo nos leva a conclusão de que o legislador optou por adotar expressamente duas teorias para justificar o exercício da jurisdição

${ }_{65}$ Casos conjuntos 89, 114, $116-117$ : 125-129/85, A. Ahlström Osakeyhtio and Others v. Comission (Woodpulp I). 1988, ECR 5193. U tribunal considerou que "/t is immaterial in that respect whether or not they had recourse to subsidiaries, agents. sub-agents, or branches within the Community in order to make their contracts with purchasers within the Community" Em tradução livre: "F́ irrelevante para esses efeitos (condenação) se (a empresa) recorreu a suas subsidiárias. agentes, sub-agentes ou filiais dentro da Comunidade para fazer seus contratos com os compradores dentro da Comunidade"

${ }_{66}$ Viho v. Comission. ECJ julgamento de 24 de outubro de 1996, ECR I - 5457. 
extraterritorial do Estado. A primeira tem por base o princípio da territorialidade, contemplada no trecho referente "às práticas cometidas no todo ou em parte no território nacional" e a segunda tem por base o princípio dos efeitos territoriais (potenciais ou reais), contemplada no trecho "ou que nele produzam ou possam produzir efeitos"

Pelo princípio da territorialidade, estão sujeitas à jurisdição do Sistema Brasileiro de Defesa da Concorrência $(\mathrm{SBDC})^{67}$ as práticas cometidas inteiramente ou em parte no território nacional. Interessa, portanto, o local da atividade. Tendo a prática sido iniciada, concluída ou cometida inteiramente no Brasil, estaria sujeita à lei antitruste nacional. Porém, como visto acima, pelo princípio da territorialidade são os efeitos do ato cometido no todo ou em parte no território nacional que coloca o Estado em posição legítima para se julgar competente para conhecer o ato. ${ }^{68}$ Assim, no caso de condutas iniciadas ou concluídas no território nacional, para a lei nacional ser aplicada, têm as mesmas que afetar de algum modo, ainda que potencialmente, o mercado nacional. Em outras palavras, atos sem quaisquer conseqüências no território brasileiro não merecem ser analisados pelo SBDC. ${ }^{69}$

Por sua vez, pelo princípio dos efeitos territoriais, aplica-se a lei antitruste brasileira toda vez que o ato causar efeitos reais ou potenciais no país. Como já foi visto, a teoria dos efeitos territoriais surge em decorrência de uma evolução da teoria da territorialidade e é mais ampla que esta. Ressalte-se que o legislador optou por não

67 O SBDC é formado pelos seguintes órgãos da Administração Pública: Secretaria de Acompanhamento Econômico do Ministério da Fazenda (SEAE), Secretaria de Direito Econômico do Ministério da Justiça (SDE), por meio de seu Departamento de Proteção e Defesa Econômica (DPDE), e Conselho Administrativo de Defesa Econômica do Ministério da Justiça (CADÊ). Tais entes atuam tanto no controle de estruturas, que analisa fusões, aquisições. joint ventures e outras transações que resultem $\mathrm{cm}$ concentração econômica ou de qualquer modo possam afutar a livie concorrência, quanto no controle de condutas, que objetiva reprimir as infrações à ordem econômica. A SEAE emite pareceres econômicos não vinculativos a respeito de transações sujeitas ao controle das estruturas e possui poderes gerais de monitoramento de preços em diversos setores da economia. Quanto ao controle de condutas, apesar da SEAE não ser obrigada a emitir parecer em um dado processo. o órgão opta por se manifestar nos casos de maior relevància. Por sua ve $\%$ a SDI é o principal órgão investigador de condutas anticompetitivas e emite pareceres jurídicos não vinculativos no que diz respeito ao controle de estruturas e de condutas. Finalmente. o CADÊ é uma autarquia que exerce as funções de tribunal administrativo, decidindo na esfera administrativa todas as questões relacionadas ao controle de estruturas e de condutas. A Constituição Federal Brasileira garante a revisão judicial de qualquer decisão oriunda de um processo administrativo.

68 Nesse sentido, ver José Carlos de Magalhães. "A aplicação extraterritorial de leis nacionais", cit., p. 94. e Darwin Lourenço Corrêa, Jurisdição Extraterritorial em Direito Antitruste, Dissertação de Mestrado, Faculdade de Direito da Universidade de São Paulo, São Paulo, 2002. p. 154.

69 Por exemplo, imagine duas empresas sediadas no Brasil que decidam constituir uma joint venture na China para fabricação de um produto que será vendido exclusivamente naquele pais por um tempo determinado para atender demanda especifica daquele mercado. Deveria este ato ser apresentado ao SBDC somente porque $o$ acordo foi realizado no Brasil? Entendemos que a resposta é negativa, haja vista que inexistem efeitos do ato no pais (reais ou potenciais). 
qualificar quais efeitos são suficientes para autorizar a jurisdição extraterritorial do Brasil apenas determinou que os efeitos devem ser reais ou potenciais.

Em vista desse silêncio da lei, a jurisprudência do Conselho Administrativo de Defisa Econômica (CADÊ) vem aos poucos tentando fixar critérios para o exercício da jurisdição brasileira sobre atos de concentração entre empresas estrangeiras que causem efeitos no país. Merecem ser analisados os casos em que o CADE julgou-se incompetente para conhecer um ato, dentre os quais destacam-se os referidos abaixo. ${ }^{70}$

No caso Pacific Cycle, LLC e Schwinn/GT Corp., ${ }^{11}$ o CADÊ. determinou o arquivamento do processo sem julgamento de mérito uma vez que entendeu que uma operação que envolve empresas sem qualquer tipo de representação própria no Brasil e que apenas uma delas tinha vendas insignificantes ao Brasil (inferiores a $0.5 \%$ do mercado relevante) por meio de revendedores independentes não deveria ser submetida ao SBDC.

Esse entendimento foi aplicado no julgamento do caso Assa Abloy $A B e$ Besam $A B,{ }^{72}$ que envolvia empresas suecas. A Besam $\mathrm{AB}$ atuava no mercado brasileiro por meio de poucas exportações, sendo que no ano anterior à operação havia vendido uma única porta no Brasil. A Assa Abloy não oferecia qualquer produto ou serviço no Brasil no mercado relevante da operação. O CADÊ considerou que a operação era incapaz de causar efeitos no Brasil, ainda que potenciais, arquivando o processo $\mathrm{sem}$ julgamento de mérito.

Merece destaque ainda o entendimento do CADÊ. no caso The Curlyle Group e Qinetiq Group Plc., ${ }^{73}$ em que o primeiro grupo adquiria este último. O Qinetiq Group era grupo britânico que não possuía ativos ou estabelecimento no Brasil, atuando

70 Em outros casos, a discussão dos efeitos de uma operação no Brasil também foi travada. Apesar da maioria do Plenário do CADE haver decidido pelo conhecimento da operação, ficou clara a emergência de um novo entendimento nesse tema por parte de alguns Conselheiros: (i) AC n. 08012.002395/2003-17. Blossomgrange Limited e Halliburton ('ompany, Relator: Conselheiro Thompson Andrade, d.j. 25 de junho de 2003; (ii) AC' n. 08012.007073/2002-75, General Dynamics Corporation e EWK Eisenwerke Kaiserslautem GmbH. Relator: Conselheiro Roberto Pfeifler. d.j. 26 de Tevereiro de 2003; (iii) AC $\mathrm{n}^{\circ}$ 08012.004181/2001-13, TD Capital Canadian Private Equity Partners (QLP) L.P. e Harrowston Inc., Relator: Conselheiro Thompson Andrade, d.j. 30 de outubro de 2002; (iv) AC n. 08012.007807/2001-35, Denso Corporation, Magneti Marelli S.p.A. e Magnetti Marelli Holding S.p.A.. Relator: Conselheiro Roberto Pfeiffer, d.j. 16 de oulubro de 2002; (v) AC n. 08012.002875'2002-99. Regis Corporation e Gameo International Limited, Relator: Conselheiro Fernando Marques, d.j. 2 de outubro de 2002: e (vi) AC n. 08012.003626/2002-11. Sears, Roebuck and Co., L.P. c Inlet Acquisition Corp.. Relator: Conselheiro Thompson Almeida Andrade, d.j. 11 de sctembro de 2002.

71 AC n. 08012.006025/2001-89; Relator: Conselheiro Ronaldo Macedo Júnior: d.j. 22 de maio de 2002. Tratava-se da aquisição de ativos da Schwinn/GT Corp. pcla Pacific Cycle, LLC, ambas empresas norteamericanas.

72 AC n. 08012.003246/2002-86; Relator: Conselheiro Thompson Andrade: d.j. 4 de selembro de 2002.

73 AC n. 08012.009254/2002-36: Relator: Conselheiro Fernando Marques: d.j. I.3 de agosto de 2003. 
no país apenas por meio de exportações esporádicas. Por sua vez, o The Carlyle Group. de origem norte-americana, não detinha qualquer empresa ativa nos mesmos ramus de atividades da empresa-alvo. O CADÊ não conheceu a operação, arquivando-a sem julgamento de mérito, em vista da inexistência de efeitos no território brasileiro. Tais entendimentos foram confirmados mais recentemente nos casos NSK Ltd. e NSK Torrington Co. Lid. ${ }^{i 4}$ e Eastman Kodak Company e Practiceworks. Inc. ${ }^{75}$

Mais recentemente (janeiro de 2005), o CADÉ passou a sustentar que o critério de notificação relativo ao faturamento, previsto no $\S 3^{\circ}$ do art. 54 da Lei n. 8.884/94 (RS 400 milhões), deve ser entendido como o faturamento do grupo econômico a que as partes fazem parte no Brasil $^{76}$ e não mais no mundo, como vinha sendo entendido de forma pacífica desde $1996 .{ }^{77} \mathrm{~A}$ justificativa é que, com esse novo entendimento, apenas as operações que têm algum potencial de causar cfeitos no país serão apresentadas ao SBDC. Assim, uma notificação somente será justificada se o grupo econômico envolvido tiver um nível de atividades significativo no pais (ao menos RS 400 milhões) ou a parte detiver ao menos $20 \%$ do mercado relevante (em conjunto com a outra parte da operação). ${ }^{78}$

it AC n. 08012.005749/2003-77; Relator: Conselheiro Thompson Andrade; d.j. 5 de novembro de 2003. A operação não envolvia ativos ou empresas no Brasil. O CADÉ entendeu que uma operação intemacional. envolvendo a aquisição de capital social de empresa que não possui filial, agência, sucursal. escritório. agente ou representante no Brasil e que não comercializa qualquer produto no pais, não é capaz de produzir efeitos em território naciunal.

75 AC n. 08012.005925/2003-71: Relator: Conselhciro Thompson Andrade: d.j. 10 de dezembro de 2003. 0 CADÊ entendeu que uma operação realizada no exterior que não acameta concentração horizontal. consubstanciada na aquisição de empresa que não possui filial ou escritorio no Brasil e que olerecia seus produtos no pais por meio de insignificantes exportaçōes esporádicas não é capaz de produzir efeitos no território brasileiro.

76 Esse entendimento foi tirmado de forma unànime pelo CADÊ no julgamento do $\mathrm{AC}$ n. 08012.002992/2004-14, ADC Telecommunications, Inc. e Krone Intemational Holding, Inc., Relator: Conselheiro Roberto Pfeiffer. d.j. 19 de janeiro de 2005, e vem sendo seguido nos julgamentos posterioris pelos Conselheiros do CADÉ, à exceção do Conselheiro Luiz Scaloppe.

7 Tal entendimento foi firmado com o julgamento do AC n. 28/95. Nalco Chemical Company e Exxon Chemical Company. d.j. 19 de junho de 1996.

78 Com à interpretação restritiva do critério do faturamento, volta a ganhar importância o critćrio de participação de mercado. Contudo, é questionável adotar esse critério para determinar a necessidade de notificação. Definiçào de mercado relevante é algo muito subjeuvn e nem sempre é possivel ter dados confiáveis sobre o tamanho de um mercado (o que, conseqüientemente, afeta a estimativa de participação no mesmo). Não por outro molivo. as Recommended Practices for Merger Norification Procedures da International Competilion Nerwork entendem que esse criterio não è adequado para determinar a obrigatoriedade de uma notificação (a recomendaçào geral é que critérios de notificação devem ser quantiticaveis de forma objetiva). Corre-se o risco de operaçòes que poderiam causar efeitos no pais não sejam notificadas em decorrência da subjetividade do critério da participação de mercado. Na ausência de reforma legal, uma soluçăo seria, ao menos para operações intemacionais, manter a interpretação anterior quanto ao critério do faturamento, devendo o CADÊ emitir uma resolução para quantificar o critério dos efeitos previsto no artigo $2^{\circ}$ da Lei n. 8.884/94. 
Com relação à jurisdição do Brasil sobre condutas cometidas no Exterior, merecem ser citados os pareceres emitidos pela Secretaria de Acompanhamento Econômico (SEAE) em conexão com a investigação no país do cartel internacional das vitaminas $^{79}$ e das lisinas. ${ }^{80} \mathrm{Em}$ ambos os casos, a SEAE sugeriu a condenação das representadas, uma vez que a conduta teria gerado efeitos no Brasil em vista do alto volume de exportações que as empresas envolvidas no cartel tinham para o país.

No que se refere ao alcance das condutas cometidas por matriz estrangeira por meio de subsidiária aqui situada, o Brasil optou por seguir a mesma linha de outras jurisdições. Matriz e subsidiária, a despeito de terem personalidade jurídica distinta, são consideradas entes únicos para os fins de aplicação antitruste. Pelo reduzido número de investigações relacionadas a condutas internacionais, analisemos novamente o cartel das lisinas, em fase de instrução. ${ }^{81}$ Neste caso, a conduta concertada foi planejada e articulada no exterior exclusivamente por sociedades estrangeiras, sendo que as subsidiárias brasileiras vendiam os produtos no país. Por serem considerados entes com unidades de interesses, as autoridades indicaram como algumas das representadas as subsidiárias brasileiras controladas pelas empresas estrangeiras integrantes do cartel $^{82} \mathrm{e}$ não as matrizes, tendo em vista a facilidade do alcance da subsidiária.

Esse entendimento é seguido com relação a atos de concentração. Como já comentado, a Lei n. 8.884/94 aponta como um dos critérios para apresentação de atos de concentração faturamento bruto anual no último exercício equivalente a $R \$ 400$ milhões por qualquer um dos participantes. A jurisprudência do CADÊ firmou entendimento no sentido de que por "participantes" deve-se entender todo o grupo econômico, ainda que a parte do ato de concentração seja uma subsidiária e não a matriz, em vista da unidade de seus interesses" $\$ 3$

79 PA n. 08012.004599/99-18. Parecer n. 210/2002/ COGDC/SEAE/MF, de 17 de dezembro de 2002. O processo ainda encontra-se em instrução. PA nº 08012.004599/99-18. Parecer n. $210 / 2002 /$ COGDC/SEAE/MF. de 17 de dezembro de 2002. O processo ainda encontra-se em instrução.

80 PA n. 08012.004897/00-23. Parecer n. 209 2002/COGDC-DF/SEAE/MF, de 17 de dezembro de 2002. O processo ainda encontra-se em instrução.

81 PA n. 08012.004897/00-23.

82 Como a ADM Exportadora e Importadora S.A., subsidiária da ADM Co., e a Ajinomoto Interamericana Ind. e Com, subsidiária do Ajinomoto Co. Inc.

83 Deve-se citar como precedentes o caso Nalco/Exxon referido acima. Ainda, nu caso Indústrias Quimicas Elgin Lida. e Sherwin Williams Brasil Indústria e Comércio Ltda., AC n. 08012.002730-98-4I. julgado em 19 de agosto de 1998, foi entendido que "E óbvio que o critério do faturamento a ser adotado engloba o montante realizado pelo grupo inteiro, composto por quantas forem as subsidiárias ou sucursais que o constituem... A matriz e suas filiais mantém vínculo juridico-econômico entre si, o que basta para as caracterizar como partes do mesmo grupo empresarial perante a legislação antitruste" Interessante è o caso mencionado por Isabel Vaz. "Legislação de Defesa da Concorrência c Extraterritorialidadc" in Revisıa do IBRAC, v. 4, n. 6, p. 266. As empresas sueca ASEA e suiça Brown-Boveri realizaram operação de fusão no final da década de 80 e decidiram não submetê-la ao CADÊ. As empresas atuavam regularmente no país por meio de suas subsidiárias. Em razão da unidade empresarial entre matriz e 
Por fim, analisemos os parágrafos que compõem o art. $2^{\circ}$ da Lei n. 8.884/94, transcritos abaixo:

$\S I^{\circ}$ Reputa-se domiciliada ${ }^{\text {xt }}$ no Território Nacional a empresa estrangeira que opere ou tenha no Brasil filial, agência, sucursal, escritório, estabelecimento. agente ou representante.

$\S 2^{\circ}$. A empresa estrangeira será notificada e intimada de todos os atos processuais, independentemente de procuração ou de disposição contratual ou estatutária na pessoa do responsável por sua filial, agência, sucursal, estabelecimento ou escritório instalado no Brasil.

Trata-se essencialmente de regras de caráter processual. inspiradas em normas do Código de Processo Civil (CPC), que objetivam facilitar a condução de processos no país e a posterior execução da decisão administrativa proferida pelo CADÊ. $\mathrm{O}$ art. 88 do CPC determina que é considerada domiciliada no Brasil a pessoa jurídica estrangeira que tiver no país agência, filial ou sucursal. ${ }^{85}$ Por sua vez, o artigo 12 do mesmo diploma legal prevê que será representada em juízo, ativa e passivamente. a pessoa juridica estrangeira pelo gcrente, representante ou administrador de sua filial, agência ou sucursal, aberta ou instalada no pais. $\mathrm{O} \$ 3^{\circ}$ do citado artigo determina que o gerente da filial ou agência presume-se autorizado pela pessoa jurídica estrangeira a receber citação inicial para o processo de conhecimento, de execução, cautelar e especial. $^{86}$

Como se vê, o $\$ 1^{0}$ do art. $2^{\nu}$ da lei antitruste ampliou o quanto previsto no art. 88 do ( $P C$, incluindo em sua redação o agente ou representante da empresa estrangeira. Isso porque se presume que os mesmos têm com a empresa estrangeira relacionamento regular, o que possibilita o alcance mais rápido da empresa estrangeira. ${ }^{87}$

subsidiária (o que fazia com que o critirio do faturamento mundial, como entendido àquele ípoca, fosse preenchido), o CADÊ solicitou às subsidiárias que apresentassem a operação intemacional ao órgão. o que foi feito em seguida.

8: A redação anterior à dada pela Lei 10.149, de 21 de dezembro de 2000, usava o termo situada no lugar de domiciliada. A mudança deu-se para compatibilizar o determinado nesse artigo com o disposto no artigo 88, I, do Código de Processo Civil ("E competunte a autoridade judiciária brasileira quando o réu. qualquer que seja a sua nacionalidade, estiver domiciliado no Brasil").

\$5 Prevê o artigo 64 do Decreto-Lei n. 2.627, de 26 de setembro de 1940, em vigor segundo o estabelecido pelo artigo 300 da Lei n. 6.404 , de 15 de dezembro de 1976, que as sociedades estrangeiras não podem sem autorizaçào do Govemo Federal funcionar no pais, por si mesmas ou por filiais. sucursais, agências ou estabelecimentos que as representem.

86 Os dispositivos do CPC aplicam-se subsidiariamente àqueles da lei n. 8.884/94. conforme o artigo 83 dessa última lei.

87 Note que, ao considerar domiciliada a empresa estranguira que opere ou tenha no Brasil filial, agência, sucursal, escritório, estabelecimento, agente ou representantc. cria-se a ficção legal de que os atos cometidos pela empresa estrangeira devem ser considerados como cometidos no pais por meio desses agentıs. Porèm, a referência a "operar" não indica o nível de vendas que deve ser considcrado suficiente 
A previsão do $\S 2^{\circ}$ visa igualmente a facilitar o alcance da empresa estrangeira. Não será necessária a emissão de cartas rogatórias para que seja determinada a citação da empresa estrangeira, porque esta será citada na pessoa do responsável por sua filial, agência, sucursal, estabelecimento ou escritório instalado no Brasil, independentemente de procuração ou de disposição contratual ou estatutária.

Está em linha com esses dispositivos o previsto no $\S 4^{\circ}$ do art. 26 da Lei $n$. $8.884 / 94,{ }^{8 \Omega}$ que prevê que responde solidariamente pela multa ali prevista a filial, sucursal, escritório ou estabelecimento no Brasil de empresa estrangeira.

No processo que investiga o cartel internacional das Usinas, interessantemente uma das representadas é a Sumitomo Corporation do Japão, que possui contrato de distribuição com a FERMEX Fermentaciones Mexicanas S.A., subsidiária mexicana da Kyowa Hakko Kogyo Company Limited, esta sim uma das empresas participantes do cartel. A decisão por indicar como representada a Sumitomo Corporation do Japão é porque é mais fácil conduzir um processo com as partes domiciliadas no Brasil do que ter que esperar que o processo caminhe com base em cartas rogatórias.

Obviamente. o fato de uma empresa estrangeira não ter qualquer tipo de presença local no pais não afasta a possibilidade de a mesma ser parte em um processo que investiga uma conduta que tenha causado efeitos no pais. Esse entendimento já foi firmado pelo CADÊ inclusive sob a lei antitruste anterior (Lei n. 4.137. de 10 de setembro de 1962), no julgamento da averiguação preliminar n. 80, em 4 de agosto de 1978. Entre outras, constava como representada a empresa estrangeira Ftablissement Ganois. Segundo a ementa da ata de sessão de julgamento, "nada obsta a instauração de processo administrativo por abuso de poder econômico eventualmente cometido por pessoa jurídica sediada no exterior" ${ }^{89}$ O que ocorre é que nesses casos todo o processo de instrução e julgamento será mais demorado em virtude da necessidade de emissão de cartas rogatórias e da conseqüente colaboração dos paises estrangeiros para tanto.

para autorizar o exercicio da jurisdição antitruste. Ademais, a existência de "filial, agência, sucursal, escritório, estabelecimento, agente ou representante" no pais nada indica sobre a real presença de uma empresa estrangeira no territónio brasileiro. Imagine-se o caso de uma empresa estrangcira que opere nu país via representante e que tenha aqui vendas insignificantes e incgulares: são praticamente inexistentes os efeitos dessa prática no pais. Nesses casos, faz-se necessário, portanto, lançar mão da teoria dos efeitos. conforme entendimento jurisprudencial e interpretação razoável da leí.

88 Incluido pela Lei n. 10.149/00.

89 Cf. José Ignácio Gonzaga Franceschini; José Luiz Vicente Franceschini, Poder económico: exercicio $c$ abuso. São Paulo: Revista dos Tribunais, 1985, p. 54. Tal entendimento superou o anteriormente expressado pelo (ADÉ no julgamento da averiguação preliminar n. 55, em 29 de outubro de 1975. Entendeu-se que a empresa inglesa Intemational Electric Association. Lid. não poderia constar como representada no processo uma vez que não possuia existència legal no pais. 
Finalmente, deve-se notar que a aplicação extraterritorial pelas autoridades de defesa da concorrência brasileiras de sua legislação nunca chegou a gerar conflitos jurisdicionais notáveis com outras auturidades. A crítica à sua ampla aplicação está nos elevados custos associados à análise de operações irrelevantes para o mercado brasileiro, que geram nele efeitos insignificantes, custos estes arcados tanto pelo poder público quanto pelos particulares. Felizmente, as autoridades parecem estar atentas à questão e é esperada para um futuro próximo uma significativa redução nos atos apresentados ao SBDC que não têm potencial de afetar o país.

5. Crises provocadas pelo exercício da jurisdição extraterritorial das leis antitruste

O exercício amplo da jurisdição extraterritorial em matéria antitruste tem provocado crises entre os diferentes países, que tiveram seu auge na década de 70 e 80 . Segundo a reação do Estado estrangeiro, essas crises podem ser divididas em recusa de colaborar, intervenções legislativas e queixas por via diplomática. Cada um desses tipos será tratado brevemente a seguir.

A recusa de colaborar por parte das autoridades estrangeiras se manifesta por meio da recusa de assistência à outra jurisdição tanto para o auxílio na fase de investigação quanto para o auxílio na fase de execução da sentença.

Um exemplo de recusa de colaborar foi a negativa inglesa de executar a sentença dos Estados Unidos no caso United States v. Imperial Chemical Industries. ${ }^{90} \mathrm{De}$ acordo com o juiz inglês, no julgamento a favor da empresa britânica British Nylon Spinners, afetada pela decisão norte-americana, a Inglaterra não reconhece aos tribunais americanos a autoridade para dar ordens que destruiriam ou qualificariam aqueles direitos pertencentes a um nacional inglês, que não é sujeito à jurisdição dos tribunais dos Estados Unidos. Outro exemplo foi a recusa das autoridades canadenses de dar curso às cartas rogatórias emitidas pelos Estados Unidos no âmbito da investigação do cartel do urânio durante a década de $70 .^{91}$

As intervenções legislativas são as iniciadas no âmbito do Poder Legislativo tomadas pelos paises que se sentem ameaçados pelo amplo exercício extraterritorial da jurisdição de um outro Estado. Tais intervenções deram lugar ao que ficou conhecido como leis de bloqueio (blocking statutes). Foi nos anos 70 que houve a edição de um grande número de leis de bloqueio, principalmente por parte de Austrália,

90 U.S. v. Imperial Chemical Industries ıt ci. 100 F. Supp. 504 (S.D.N.Y. 1951). Neste caso, a empresa norteamericana DuPont de Nemours e a inglesa Imperial ('hemical Industries foram acusadas de dividir o mercado mundial de nylon.

91 Cf. decisão da Suprema Corte do Canadá no caso Gulf Oil Corp. v. Gulf Canada Lıd, III D.L.R. 3d 74 (1980). 
Canadá, França, Nova Zelândia e Reino Unido em reação à atuação ampla dos Estados Unidos no caso do cartel do urânio.9?

Há três graus de leis de bloqueio. O primeiro deles engloba leis que impedem que pessoas nacionais (tĩsicas ou jurídicas) divulguem certos documentos que estão em seu poder a autoridades estrangeiras. A lei francesa n. 80-538, de 16 de julho de 1980, que considera ilícito penal a entrega de documentos relacionados a assuntos técnicos para uso em julgamento no exterior (exceção é feita para aqueles julgamentos autorizados por tratados internacionais). é um exemplo. ${ }^{93} \mathrm{O}$ segundo grau está ligado ao reconhecimento de sentenças estrangeiras. Como exemplo podem ser citadas a lei britânica Protection of Trading Interests Act, de 1980, e a lei canadense Loi sur les mesures extruterrituriales étrungères, de $1984 .{ }^{94} \mathrm{O}$ terceiro grau de leis de bloqueio. conhecidos como cluwback statutes, ${ }^{4 / 5}$ permite aos condenados nos Estados Unidos por treble damages recuperar em seus países os valores que excedam a simples reparação do dano. A lei britânica e a lei canadense acima citadas têm previsões nesse sentido e a Austrália editou lei para tratar dessa questão. ${ }^{46}$

As crises diplomáticas são o outro tipo de crise iniciada por parte dos Estados que se vêem lesados pela aplicação extraterritorial da legislação antitruste. Uma das mais conhecidas foi provocada pelo processo instaurado nos Estados Unidos relativo ao caso U.S. v. The Watchmakers of Switzerland Information Center. ${ }^{97}$ O processo analisava um conjunto de acordos relativos à exportação de relógios e de peças para relógios da Suíça para os Estados Unidos, tidos como ilícitos. Apesar de admitir que a indústria de relógios era uma das principais atividades da Suíça, o Tribunal norteamericano exigiu várias mudanças em sua estrutura em uma primeira sentença. Após várias manifestações e ameaças de levar o pais à Corte Internacional de Justiça, o Departamento de Justiça dos Estados I Inidos requereu ao juiz que revisasse sua decisão,

92 Nesse sentido, ver Joseph P. Griffin, "Foreign Governmental Reactions to I:S. Assertions of Fxtraterritorial Jurisdiction", 6 Geo. Mason Law Review 505, 1998.

93 Sobre, ver Drake D. McKenney \& Vicent Mercier. "Obtaining Evidence in France for use in L'nited States Litigation" in Tulane Journal of International and Comparative Law, v. 2. p. 91-119, 1994.

94 A lei canadense permite ao Estados não reconhecer decisões antitruste alienigenas se elas atentam contra sua soberania e os interesses nacionais. Os termos da lei britânica vão um pouco mais alèm ao nãu imporem cssas condições para o não reconhecimento das sentenças.

95 Cl. Joseph E. Neuhaus, "Power to Reverse Foreign Judgments: The British Clawback Statute under International Law", 81 Columbia Low Review, 1097, 1981.

96 Foreign P roceedings Excess of Jurisdiction Acr. de 1984.

97 L.S. v. The Watchmakers of Swizerland Information Center Inc., 133 F.Supp. 40 (1955). 
o que foi feito em 1965. Outros casos notórios em que houve queixas por via diplomática são os recentes Boeing/McDonnell Douglas ${ }^{98}$ e GE/Honeywell. ${ }^{99}$

6. Perspectivas

Atualmente, mais de noventa países contam com legislação de defesa da concorrência, a maioria deles com previsões de exercício de jurisdição extraterritorial, e a tendência é que esse número aumente. Dentro deste contexto, é cada vez mais significativo o percentual de casos que envolvem elementos estrangeiros analisados pelas autoridades antitruste. ${ }^{100}$

Esse dado evidencia ainda mais os limites do unilateralismo. Em estruturas, o risco de emissão de decisões contraditórias pelas diferentes autoridades de defesa da concorrência não pode ser desconsiderado, o que causa um aumento de custos e incerteza para as partes e, na pior das hipóteses, a desistência de se celebrar uma operação pró-concorrencial. ${ }^{101}$ Há outras tantos custos associados à existência de

W. A operação consistiu na aquisição da McDonnell Douglas pela Boeing, ambas importantes cmpresas do setor de aviação, em 1996. Em junho de 1997, a Comissão Européia notificou às autoridades americanas suas preocupações. tendo solicitado à FTC que levasse em consideração os interesses da União Européia com o fim de salvaguardar a concorrência no mercado dos grandes aviōes civis. Em $1^{\circ}$ de julho de 1997. a FTC fez pública sua decisão de não barrar a operação. Em seguida, em 4 de julho, a Comissão Européia concluiu preliminarmente pela não aprovação da operação. Começou ai um periodo de negociação intensa entre as duas autoridades, que incluiu queixas por via diplomática (o então presidente Bill Clinton chegou a dizer que se houvesse reprovação da operação recorreria à Organização Mundial do Comércio). A Comissão Européia tomou em consideração ussas queixas e decidiu limitar sua atuação ao dominio civil da operação, não interferindo nos interesses americanos no setor de defesa. Em 30 de julho de 1997, a Comissão Européia decidiu aprovar a operação com restrições, após concessões da Boeing para aumentar a concorrência (Decisão (CE) n. 97/816, de 30.07.1997. Bocing/McDonnell Douglas, JO L 336/16, de 08.12.1997.).

99 A operação envolveu a aquisição da Honeywell, empresa norte-americana ativa principalmente no mercado de produtos e serviços aerocspaciais, pela General Electric (GE), empresa norte-americana com atividades no mercado de eletrudomésticos, equipamentos médicos, sistemas industriais, serviços financeiros e sistemas de transporte, no ano de 2000. Em maio de 2001, o Departamento de Jusliça dos Estados Unidos entrou em acordo com as partes e tomou pública sua decisão de não barrar a operação. Em julho de 2001, a Comissão Furopéia tomou pública sua decisão de reprovar a operação, uma vez que essa criaria ou reforçarıa posição dominante da $\mathrm{GE}$ em uma séric de mercados. Essa decisão foi seguida por uma séria de queixas por parte Departamento de Justiça dos Estados Unidos que não fizeram a Comissão reconsiderar sua posição. Cabe dizcr que as empresas recorreram da decisão ao tribunal comunitário, que ainda pode anular a mesma (processos T-209 Honeysell Intemational/Commission e T-210 General Electric/Commission).

100 Por exemplo. no Brasil, dos atos de concentração submetidos à análise da Coordenação-Geral de Produtos Industriais da Secretaria de Acompanhamento Econômico (COGPI/SEAE) em 2002, 66\% ocorreram em outros paises, $16,7 \%$ derivaram de entendimentos entre empresas nacionais e estrangeiras e somente $17.3 \%$ dos casos sob análise restringiram-se ao âmbito exclusivamente nacional.

Dados disponiveis em: <http://www.fazendo.gov.br/portugues/releases/2003/r030402,asp>.

101 Nesse sentido, ver Mario Monti. The EU Views on a Global Competition fónum <http://europa.eu_0| RAPID\&lg=EM $\geq$ e Charles A. James. "Perspectives on the Intemational Competition Network" ABA International Antimust Bulletin v: 4, issue 3 in <http://www.abanet.organtitrusticommittes/intemational/fallwinter)I.pdf? 
diversos sistemas de notificações antitruste, entre os quais: (i) custos associados à interpretação obscura ou ambigua de critérios de notificação de certas legislações; (ii) custos decorrentes do pagamento de taxas processuais: (iii) custos associados à compilação de informação por demais detalhada a ser incluída na notificação e em pedidos posteriores de dados há jurisdições que exigem um rigoroso grau de detalhamento de informações sobre a operação e suas partes, o que gera um gasto injustificado para as operações sem impactos concorrenciais; e (iv) custos associados à demora na análise antitruste. Em condutas, os limites do unilateralismo são evidenciados principalmente em decorrência da necessidade de colaboração da autoridade estrangeira nas fases de instrução e execução. ${ }^{102}$ Além disso. nem todos os países têm os recursos suficientes para levar a cabo investigações internacionais. Visando a suplantar esses limites, os países vêm utilizando, cada vez mais, mecanismos de cooperação internacional.

A cooperação internacional pode ser bilateral (entre dois países), ${ }^{103}$ regional (dentro de um bloco econômico) e multilateral (entre o maior número de países possivel). A partir da década de 90 houve uma proliferação dos acordos bilaterais, que constituem o atual padrão de cooperação extraterritorial. A cooperação regional e a cooperação multilateral têm também importância fundamental, destacando-se fóruns como a International Competition Network (ICN) ${ }^{104}$ e a Organização para a Cooperação e Desenvolvimento Econômico (OCDE).

Esses instrumentos, apesar de não impedirem o exercício extraterritorial da jurisdição em matéria antitruste, têm reduzido significativamente as crises decorrentes desse exercício (p.ex, as leis de bloqueio. referidas no capitulo acima. apesar de continuarem em vigor, são raramente utilizadas na prática) e tornado mais eficaz o combate a condutas internacionais, principalmente hard core cartéis. Ademais, os instrumentus de cooperação incentivam a troca de informações e assistência técnica mútua entre as auturidades, o que puderá levar. aos poucos, a uma harmunização entre as legislações.

A tendência é que a cooperação em matéria antilruste torne-se cada vez mais intensa. com acordos mais amplos (que permitam, por exemplo, a troca de

102 Ressalte-se que a grande maioria dos paises não conta cnm uma cstrutura ideal para o combate de condutas internacionais, sendu fundamental a colaboração estrangeira.

${ }^{103}$ Importante dizer que os acordos de cooperação bilaterais não são legalınente vinculativos para a grande maioria dos paises. Assim, quando impontantes interesses nacionais estão presentes, a cooperaçào bilateral pode ter seus benelicios facilmente alastados.

10: A ICN é um fórum informal de discussão e de trocas de experiència entre autoridades de paises desenvolvidos e em desenvolvimento, incentivando fortemente a cooperação. A rede tem uma estrutura virtual (o endereço é <http://www.internationalcompetitionnetwork.org >), sem secretariado permanente. organizada de forma flexivel. 
informações confidenciais entre as partes). ${ }^{105} \mathrm{O}$ Brasil vem seguindo essa tendência mundial e já firmou acordos de cooperação bilateral com Estados Unidos, ${ }^{106}$ Rússia $^{107} \mathrm{e}$ Argentina, ${ }^{108}$ procurando atuar de forma intensa em fóruns internacionais.

\section{Conclusão}

O exercício da jurisdição extraterritorial em matéria antitruste é necessário uma vez. que um mesmo ato pode afetar de forma significativa mais de uma jurisdição, sundo que cada país tende a garantir verdadeiramente a existência de um ambiente concorrencial apenas em seu território.

De modo a enfrentar adequadamente essa questão, o elemento de conexão atualmente adotado pela maioria dos paises, dentre os quais o Brasil, é o de efeitos territoriais, geralmente qualificados como diretos, significativos e razoavelmente previsiveis, conforme posição há muito defendida pelos Estados L'nidos.

$\mathrm{O}$ exercicio unilateral dessa jurisdição, entretanto, traz consigo o risco de crises entre os Fstados, que podem entender que houve violação de sua soberania. Tais limites do unilateralismo são cada vez mais evidentes em razão da internacionalização dos mercados e do crescente número de paises que adotaram legislação antitruste. Niesse contexto, as autoridades de defesa da concorrência devem empenhar-se em criar mecanismos de cooperação de modo a aumentar a efetividade das políticas nacionais de defesa da concorrência e reduzir significativamente conflitos jurisdicionais e custos para os particulares e as autoridades.

São Paulo, fevereiro de 2006.

los Esses são os chamados acordos de segunda geração. Atualmente. poucos são os paises que permitem a troca de informações confidenciais sem a prévia autorização das partes envolvidas. Os Estados Unidos reformou sua legislação. por meio da emissão do International Antitrust Enforcement Assistance Act em 1994, para permitir que o pais assinc acordos de cooperação com previsão de troca de informações conlidenciais entre as autoridades, desde que sejam observados os interesses norte-americanos. O primeiro desses acordos foi firmado em 1999 entre Estados I inidos e Austrália (I999 US/Australia Agreement on munal antirust énforcement assistance, firmado $\mathrm{cm}$ Washington, $\mathrm{cm} 27$ de abril de 1999, in <htpp://www.usdoj.gov/atr/public/international/docs/usaus7.htm>). Outras autoridades. como Canadá, já manifestaram interesse em firmar acordos com tais previsões.

106 Acordo entre u Govemo da República Federativa do Brasil e o Governo dos Estados Unidos da América relativo à cooperação entre suas autoridades de defesa da concorrència na aplicação de suas leis de concorrência. de 26 outubro de 1999.

107 Acordo entre o Governo da República Federativa do Brasil e o Governo da Federação da Rússia sobre cooperaçào na área de Política da Concorrência. de 12 de dezembro de 2001 .

108 Acordo de Cooperação entre a República Federativa do Brasil e a República Argentina relativo à cooperação intre suas autoridades de defesa da concorrincia na aplicação de suas leis de concorrência. de 16 de oulubro de 2003. 
Referências

ARELDA, Phillip \& KAPLOW. Louis. Antitrust analysis: problems, text, cases. 4 ed. Boston: Little-Brown\&Co., 1988.

CORRF̂.A, Darwin Lourenço. Jurisdição Extraterritorial em Direito Antitruste. São Paulo, 2002. Dissertação (Mestrado) - Faculdade de Direito. Universidade de São Paulo.

FRANCES(:HINI; José Ignácio Gonzaga \& FRANCESCHINI, José L.uiz Vicente. Poder econômico: exercício e abuso. São Paulo: Revista dos Tribunais. 1985.

GRIFFIN, Joseph P. Fxtraterritoriality in U.S. and EU Antitrust F.nforcement in 67 Antitrust Law Journal 159. 1999.

. EC and U.S. Extraterritoriality: Activism and Co-operation in Fordham International Law Journal, 1993.

Foreign Governmental Reactions to U.S. Assertions of Extraterritorial Jurisdiction in 6 George Mason I.aw Review 505, 1998.

HAWK, Barry F. United States, Commom Market and International Antitrust: A Comparative Guide. 2. ed. Englewood Cliffs: Prentice Hall Law \& Business, 1985 \& Supp. 1989.

HOVENKAMP, Herbert. Federal Antitrust Policy - The Law of Competition and its practice. 2. ed. St. Paul: West Group, 1999.

IDOT, Laurence. Le controle des pratiques restrictives de concurrence dons Is échanges internationaux. Thèse Paris II, 1981. 2 v.

MCKENNEY, Drake D. \& MERCIER, Vicent. Obtaining Evidence in France for use in United States Litigation. In: Tulane Journal of International and Comparative Law. v. 2, 1994. p. 91-119.

MAGALHÃES, José Carlos de. A aplicação extraterritorial de leis nacionais. Revista Forense. Rio de Janeiro, v. 293, jan./fev./mar. 1986.

NEUHAUS, Josuph E. Power to Reverse Foreign Judgments: The British ('lawback Statute under International Law. In: 81 Columbia Law Review. 1097. 1981.

RENOLD, Marc-André. Les conflits de lois en droil antitrust Contribution à Vétude de Vapplication internationale du droit économique. Zürich: Schulthess Polygraphischer Verlag, 1991.

ROBERTSON, Aidan; DEMETRIOU, Marie. But that was in another country...: The extraterritorial application of US antitrust laws in the US Supreme Court. In: International and Comparative Law Quarterly 43, part. 2. Glasgow, Bell and Bain Ltd., 1994. 
SICILIAN, James; WELLMAN, Philip S. The Extraterritorial Application of the US Antitrust to Criminal Conspiracies. European Competition Law Review, 151, 1988.

U.S. DEPARTMENT OF JUSTICE; THE FEDERAL TRADE COMMISSION. Antitrust Enforcement Guidelines for International Operations. [s.l., s.n.], 1995.

VAZ, Isabel. Legislação de Defesa da Concorrência e Extraterritorialidade. Revista do IBRAC, v. 4, n. 6 .

ZANETTIN, Bruno. Cooperation between antitrust agencies at the International levei. Oxford. Portland: Hart Publishing, 2002.

ZWARENSTEYN. Hendrik. Some aspects of the extraterritorial reach of the American antitrust laws. Deventer: Fred B. Rothman \& Co.. 1970. 